\title{
Cervical Mullerian Papilloma
}

National Cancer Institute

\section{Source}

National Cancer Institute. Cervical Mullerian Papilloma. NCI Thesaurus. Code C40215.

A rare, benign, papillary neoplasm that arises from the cervix. It is characterized by the presence of a fibrovascular core covered by mucinous epithelial cells. 